\title{
Regulating Oral Biofilm from Cariogenic State to Non-Cariogenic State via Novel Combination of Bioactive Therapeutic Composite and Gene-Knockout
}

\author{
Hong Chen ${ }^{1,2,3}$, Yingming Yang ${ }^{1}$, Michael D. Weir ${ }^{3}$, Quan Dai ${ }^{3,4}$, Lei Lei ${ }^{1}$,

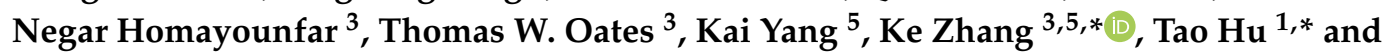 \\ Hockin H. K. Xu ${ }^{3,6,7, *}$
}

1 State Key Laboratory of Oral Diseases, Department of Operative Dentistry and Endodontics, West China School of Stomatology, National Clinical Research Centre for Oral Diseases, Sichuan University, Chengdu 610041, China; 501411@cqmu.edu.cn (H.C.); ymyang@scu.edu.cn (Y.Y.); leilei@scu.edu.cn (L.L.)

2 Department of Conservative Dentistry and Endodontics, College of Stomatological, Chongqing Medical University, Chongqing Key Laboratory of Oral Diseases and Biomedical Sciences, Chongqing Municipal Key Laboratory of Oral Biomedical Engineering of Higher Education, Chongqing 401147, China

3 Department of Advanced Oral Sciences and Therapeutics, University of Maryland Dental School, Baltimore, MD 21201, USA; MWeir@umaryland.edu (M.D.W.); qdai@umaryland.edu (Q.D.); nhomayounfar@umaryland.edu (N.H.); toates@umaryland.edu (T.W.O.)

4 Clinical Research Center of Shanxi Province for Dental and Maxillofacial Diseases, Key Laboratory of Shaanxi Province for Craniofacial Precision Medicine Research; College of Stomatology,

Xi'an Jiaotong University, Xi'an 710004, China

5 Department of Orthodontics, School of Stomatology, Capital Medical University, Beijing 100069, China; dr_yangkai@163.com

6 Center for Stem Cell Biology \& Regenerative Medicine, University of Maryland School of Medicine, Baltimore, MD 21201, USA

7 Marlene and Stewart Greenebaum Cancer Center, University of Maryland School of Medicine, Baltimore, MD 21201, USA

* Correspondence: tuzizhangke@163.com (K.Z.); hutao@scu.edu.cn (T.H.); hxu@umaryland.edu (H.H.K.X.)

Received: 27 August 2020; Accepted: 11 September 2020; Published: 13 September 2020

\begin{abstract}
The objectives were to investigate a novel combination of gene-knockout with antimicrobial dimethylaminohexadecyl methacrylate (DMAHDM) composite in regulating oral biofilm from a cariogenic state toward a non-cariogenic state. A tri-species biofilm model included cariogenic Streptococcus mutans (S. mutans), and non-cariogenic Streptococcus sanguinis (S. sanguinis) and Streptococcus gordonii (S. gordonii). Biofilm colony-forming-units (CFUs), lactic acid and polysaccharide production were measured. TaqMan real-time-polymerase-chain reaction was used to determine the percentage of each species in biofilm. The $r n c$ gene-knockout for S. mutans with DMAHDM composite reduced biofilm CFU by five logs, compared to control $(p<0.05)$. Using parent $S$. mutans, an overwhelming S. mutans percentage of $68.99 \%$ and $69.00 \%$ existed in biofilms on commercial composite and $0 \%$ DMAHDM composite, respectively. In sharp contrast, with a combination of S. mutans $r n c$ knockout and DMAHDM composite, the cariogenic $S$. mutans percentage in biofilm was reduced to only $6.33 \%$. Meanwhile, the non-cariogenic S. sanguinis + S. gordonii percentage was increased to $93.67 \%$. Therefore, combining $r n c$-knockout with bioactive and therapeutic dental composite achieved the greatest reduction in S. mutans, and the greatest increase in non-cariogenic species, thereby yielding the least lactic acid-production. This novel method is promising to obtain wide applications to regulate biofilms and inhibit dental caries.
\end{abstract}

Keywords: multi-species biofilm; S. mutansrnc gene-knockout; bioactive composite; regulating biofilm composition; biofilm-material interactions; dental caries 


\section{Introduction}

To date, over 700 phylotypes have been found in the oral cavity of healthy people and people with diseases [1]. Even healthy people can present cariogenic bacteria [2,3]. It is important to maintain the balance of oral microbiome for oral and body health $[4,5]$. Dental caries is one of the most widespread and costly biofilm-mediated oral infectious diseases, affecting all ages of people worldwide [6,7]. Dental caries is associated with dysbiosis of the tooth-colonizing microbiota, with the species types in the dental plaque biofilm shifting from a healthy composition toward a cariogenic composition $[8,9]$. This causes a microbial shift of dental plaque, increasing the growth and metabolism of cariogenic bacteria while inhibiting the beneficial organisms [10]. Oral streptococci are the early colonizers, and their initial adhesion determines the species composition in the oral biofilm and impacts on the health status of the host [11]. Interspecies interactions of oral streptococci play an important role in the biofilm shift [12]. Previous studies established a three oral streptococci species model: cariogenic Streptococcus mutans (S. mutans), and noncariogenic Streptococcus sanguinis (S. sanguinis) and Streptococcus gordonii (S. gordonii) [12]. This three-species biofilm model is referred to as the Sm $+\mathrm{Ss}+\mathrm{Sg}$ biofilm model in the present paper. These three species compete for adhesion-binding sites on the tooth surface, and compete for carbohydrates [13]. Among them, S. mutans can reduce plaque $\mathrm{pH}$ upon the ingestion of fermentable carbohydrate, and induce the selection for a cariogenic flora at the expense of the healthy and less aciduric residents, leading to lower proportions of S. sanguinis and S. gordonii in the biofilm $[14,15]$. On the other hand, S. sanguinis and S. gordonii can generate $\mathrm{H}_{2} \mathrm{O}_{2}$ to decrease the growth of $S$. mutans $[12,14]$.

Resin composites are popular dental materials to restore tooth cavities. However, compared with amalgam and glass ionomers, resin composites tend to collect more biofilms [16,17]. Biofilm acids can lead to tooth mineral dissolution, causing tooth decay. Therefore, secondary caries (recurrent caries) is one of the major reasons for the failure of tooth cavity restorations [18-20]. As a result, there is an urgent need to develop a new generation of bioactive and therapeutic dental resin composites to control oral biofilms and inhibit tooth decay.

Quaternary ammonium methacrylates (QAMs) are cationic and can be co-polymerized in dental resin to obtain long-term contact-inhibition against bacteria [21-23]. In previous studies, several novel QAMs were used in a dental product, including 12-methacryloyloxydodecyl-pyridinium bromide (MDPB) [24], quaternary ammonium dimethacrylate (QADM) [25], quaternary ammonium-polyethylenimine (QPEI) [26,27], methacryloxylethyl cetyl dimethyl ammonium chloride (DMAE-CB) [28], dimethylaminododecyl methacrylate (DMADDM) [29] and dimethylaminohexadecyl methacrylate (DMAHDM) [30]. In addition, these QAMs with varying alkyl chain lengths had acceptable low cytotoxicity against human gingival fibroblasts and odontoblast-like cells, matching the low cytotoxicity of commercial dental monomers in clinical use [31,32]. DMAHDM with an alkyl chain length of 16 was incorporated into resins and presented a strong antimicrobial ability with a low level of cytotoxicity [30,32]. Several studies showed the ability of QAMs to modulate oral biofilm composition to promote noncariogenic species and suppress cariogenic species $[7,8]$.

As we have recently learned, the genes and pathways of $S$. mutans play an important role in the interactions with anti-caries compounds [33,34]. The $r n c$ gene is a post-transcriptional regulator gene in S. mutans, and previous studies proved a knockout of $r n c$ gene in S. mutans could suppress acid production and inhibit caries [35,36]. However, these studies tested a single species biofilm, and did not test biofilm growth and species modulation on composite surfaces. To date, there has been no report on the effects of $r n c$ knockout in S. mutans on the modulation of bacterial species in the Sm + Ss + Sg biofilm; it is unknown whether rnc knockout would shift the biofilm composition from a cariogenic state toward a non-cariogenic healthy composition. Furthermore, there has been no report on the effects of combining rnc knockout in S. mutans with DMAHDM composite on the modulation of the $\mathrm{Sm}+\mathrm{Ss}+\mathrm{Sg}$ biofilm.

Therefore, the objectives of this study were to investigate, for the first time: (1) the effect of $r n c$ gene knockout in S. mutans on species proportional shift in a tri-species biofilm model (S. mutans, 
S. sanguinis, and S. gordonii); (2) the dual strategy of combining the $r n c$ gene-knockout for S. mutans with a bioactive and therapeutic composite in regulating the biofilm to shift from a cariogenic state toward a non-cariogenic state. It was hypothesized that: (1) The S. mutans rnc gene-knockout would substantially reduce the cariogenic $S$. mutans percentage in the $\mathrm{Sm}+\mathrm{Ss}+\mathrm{Sg}$ biofilm and increase the non-cariogenic species percentage, even without the use of an antimicrobial agent; (2) DMAHDM composite would induce a shift in biofilm species from a cariogenic composition toward a non-cariogenic composition; (3) The dual strategy of combining the $r n c$ gene-knockout with DMAHDM composite would achieve the greatest reduction in S. mutans percentage in the Sm + Ss + Sg biofilm, and obtain the greatest increase in the non-cariogenic species percentage, thereby resulting in the least acid secretion by the biofilm.

\section{Materials and Methods}

\subsection{Composites Fabrication}

DMAHDM was produced using a modified Menschutkin reaction technique [37]. The main merit of this reaction is that the products need minimal purification before experimental use. Briefly, $10 \mathrm{mmol}$ of 2-(dimethylamino) ethyl methacrylate (Sigma-Aldrich, St. Louis, MO, USA), $10 \mathrm{mmol}$ of 1-bromododecane (TCI America, Portland, OR, USA), and $3 \mathrm{~g}$ of ethanol were mixed and then agitated at $70{ }^{\circ} \mathrm{C}$ for $24 \mathrm{~h}$. The ethanol solvent was eliminated via evaporation and DMAHDM was then obtained [38].

Heliomolar (Ivoclar, Amherst, NY, USA) served as a commercial control composite. According to the manufacturer, bisphenol A glycidyl dimethacrylate (BisGMA, Esstech, Essington, PA, USA) and triethylene glycol dimethacrylate (TEGDMA, Esstech) were mixed at 1:1 mass ratio (all by mass unless otherwise noted) [23,39]. Then, $0.2 \%$ camphorquinone and $0.8 \%$ ethyl $4-N, N$-dimethylaminobenzoate were incorporated for photoactivation; this resin is termed BT resin [35]. DMAHDM/(BT + DMAHDM) mass fractions of $0 \%, 5 \%$, and $10 \%$ were used. The highest concentration of $10 \%$ was chosen without compromising the mechanical property [8]. Barium boroaluminosilicate glass particles with a median size of $1.4 \mu \mathrm{m}$ (Caulk/Dentsply, Milford, DE, USA) were silanized with $4 \%$ 3-methacryloxypropyltrimethoxysilane $[35,40]$. A mass fraction of $70 \%$ of glass particles was mixed into $\mathrm{BT}$ resin, and the DMAHDM mass fractions in the composite were $0 \%, 1.5 \%$, and $3 \%$, respectively [8]. Thus, the following four groups were investigated:

(1) Commercial control: Heliomolar;

(2) $0 \%$ DMAHDM: 30\% BT + 0\% DMAHDM + 70\% glass particles;

(3) $1.5 \%$ DMAHDM: $28.5 \%$ BT + 1.5\% DMAHDM + 70\% glass particles;

(4) $3 \%$ DMAHDM: $27 \%$ BT + 3\% DMAHDM + 70\% glass particles.

To make resin disks, the molds with a diameter of $10 \mathrm{~mm}$ and a thickness of $2 \mathrm{~mm}$ was used, and then light-cured (Triad 2000; Dentsply, York, PA, USA) for $1 \mathrm{~min}$ on each side were applied [8]. The cured disks were submerged in $200 \mathrm{~mL}$ of distilled water and agitated magnetically with a bar at a speed of $100 \mathrm{r} / \mathrm{min}$ for $24 \mathrm{~h}$ [8]. Then the disks were sterilized with ethylene oxide (AnproleneAN 74i, Andersen, Haw River, NC, USA) and degassed for 3 days [23].

\subsection{Mechanical Testing}

Six specimens of $2 \times 2 \times 25 \mathrm{~mm}$ dimensions were tested for each group $(n=6)$ for load-bearing properties [39]. The specimens were photo-polymerized (Triad 2000, Dentsply, York, PA, USA) for $1 \mathrm{~min}$ on each side, and then incubated for $24 \mathrm{~h}$ at $37^{\circ} \mathrm{C}$. Flexural strength and elastic modulus were investigated via three-point flexure employing a $10 \mathrm{~mm}$ span at a crosshead speed of $1 \mathrm{~mm} / \mathrm{min}$ on a computer-controlled Universal Testing Machine (5500R, MTS, Cary, NC, USA) [40]. Flexural strength was calculated by the equation of $S=3 P_{\max } / L\left(2 b h^{2}\right)$, where $P_{\max }=$ the fracture load, $L=$ the span, $b=$ specimen width, and $h=$ specimen thickness [41]. Elastic modulus was determined by the equation 
of $E=(P / d)\left(L^{3} /\left[4 b h^{3}\right]\right)$, where load $P$ divided by the related displacement $d$ is the curve's slope in the linear elastic region [41].

\subsection{Bacterial Strains and Growth Conditions}

The use of all the bacterial species was approved by the University of Maryland Baltimore Institutional Review Board. Parent S. mutans strain UA159 (ATCC 700610) and the rnc-knockout strain were provided by West China School of Stomatology $[35,36]$. Prior to the experiments, the accuracy of the strains was verified using polymerase chain reaction (PCR) and sequencing [35]. Streptococcus sanguinis ATCC10556 (S. sanguinis) and Streptococcus gordonii ATCC10558 (S. gordonii) were obtained from American Type Culture Collection (ATCC, Manassas, VA, USA). All the bacterial strains are listed in Table 1 [35]. They were cultured in a brain-heart infusion (BHI) broth (Sigma, St. Louis, MO, USA) at $37^{\circ} \mathrm{C}$ with $5 \% \mathrm{CO}_{2}$. For $\mathrm{Sm}+\mathrm{Ss}+\mathrm{Sg}$ biofilm formation, the sterilized composite disks were placed into 24-well plates. Then, the overnight parent or rnc-knockout S. mutans, and S. sanguinis, S. gordonii were adjusted to $10^{7}$ colony-forming units (CFUs)/mL in $1.5 \mathrm{~mL}$ BHI supplied with $1 \%$ sucrose for each well [8]. For 2-day biofilms, the composite disks with biofilms were transferred to new 24-well plates filled with fresh culture medium without the washing steps after $24 \mathrm{~h}$. Then the cultures were incubated at $37^{\circ} \mathrm{C}$ with $5 \% \mathrm{CO}_{2}$ for another $24 \mathrm{~h}$. The 2-day biofilms were then used for subsequent experiments.

Table 1. Bacterial strains used in this study.

\begin{tabular}{ccc}
\hline Strain & Description & Source or Reference \\
\hline Parent S. mutans & S. mutans wild type UA159; & a ATCC 700610 \\
\hline $\begin{array}{c}\text { rnc knockout } \\
\text { S. mutans }\end{array}$ & $\begin{array}{c}\text { Smurnc; } \\
\text { The parent S. mutans UA159 with inframe } \\
\text { replacement by an erythromycin cassette }\end{array}$ & {$[33,35]$} \\
\hline S. sanguinis & S. sanguinis wild type & ${ }^{\text {a }}$ ATCC10556 \\
\hline S. gordonii & S. gordonii wild type & a ATCC10558 \\
\hline
\end{tabular}

\subsection{Live/Dead Staining Assay}

Disk samples grown with 2-day biofilms were washed with phosphate buffered saline (pH 7.4) (PBS). Live/Dead Baclight bacterial viability kits (Molecular Probes, Eugene, OR, USA) were used as reported in previous investigations [8,35]. The $2.5 \mu \mathrm{M}$ SYTO 9 and $2.5 \mu \mathrm{M}$ propidium iodide were used to label the live and dead bacterial cells, respectively. Images of five random fields of each group were captured on each disk, and three disks were used for each group, thus producing 15 images for each group.

\subsection{Colony-Forming Unit (CFU) Counts}

Biofilms grown for two days on composite disks were transferred into tubes with $2 \mathrm{~mL}$ of PBS, and the biofilms were collected by employing a sonication and vortex method (Fisher, Pittsburg, PA, USA) [42]. The bacterial suspensions were successively diluted and then moved to BHI agar plates. The agar plates were cultured at $37^{\circ} \mathrm{C}$ in $5 \% \mathrm{CO}_{2}$ for $48 \mathrm{~h}$, and the $\mathrm{CFU}$ counts were calculated by counting the colony numbers. 


\subsection{Biofilm Viability Using the MTT Assay}

The 3-(4,5-dimethylthiazol-2-yl)-2,5-diphenyl tetrazolium bromide (MTT) (VWR Chemicals, OH, USA) assay was used to estimate the viability of bacteria in biofilms [8]. Disks with 2-day biofilms were washed twice with PBS and transferred into a new 24-well plate $(n=6) .1 \mathrm{~mL}$ MTT dye $(0.5 \mathrm{mg} / \mathrm{mL}$ MTT in PBS) was added into each well and incubated at $37^{\circ} \mathrm{C}$ in $5 \% \mathrm{CO}_{2}$ for $1 \mathrm{~h}[8,29]$. The disks were then transferred to a new 24-well plate, and $1 \mathrm{~mL}$ dimethyl sulfoxide (DMSO) was added in each well at room temperature for $20 \mathrm{~min}$ to dissolve the formazan crystals. After mixing via pipetting, $200 \mu \mathrm{L}$ of the DMSO solution was collected and transferred into 96-well plate. OD540 nm was determined via the microplate reader (SpectraMax M5, Molecular Devices, Sunnyvale, CA, USA) [8].

\subsection{Polysaccharide Synthesis in Biofilms}

The water-insoluble polysaccharides production by 2-day biofilms was evaluated using a phenol-sulfuric acid method [8,40,43]. Biofilms were immersed in $2 \mathrm{~mL}$ PBS collected by sonication/vortexing. Centrifugation yielded a precipitate, which was washed twice with PBS. The precipitate was then resuspended in $100 \mu \mathrm{L}$ of distilled water. $100 \mu \mathrm{L}$ of $6 \%$ phenol solution and $0.5 \mathrm{~mL}$ of $95-97 \%$ sulfuric acid was added, followed by incubation for $30 \mathrm{~min}$. Then, $200 \mu \mathrm{L}$ of the solution was transferred into a 96-well plate and $\mathrm{OD}_{490 \mathrm{~nm}}$ was determined with the microplate reader (SpectraMax M5, Molecular Devices). Six glucose concentrations of 0, 5, 10, 20, 50 and $100 \mathrm{mg} / \mathrm{mL}$ were used to plot the standard curve of $\mathrm{OD}_{490 \mathrm{~nm}}$ readings to polysaccharide concentrations.

\subsection{Lactic Acid Secretion by Biofilms}

Disks with 2-day biofilms were rinsed twice with PBS and removed to a new 24-well plate. They were immersed in $1.5 \mathrm{~mL}$ buffered peptone water (BPW, Sigma-Aldrich) with $0.2 \%$ sucrose and incubated at $37^{\circ} \mathrm{C}$ in $5 \% \mathrm{CO}_{2}$ for $3 \mathrm{~h}(n=6)$ [25]. The lactate concentrations in BPW were determined using an enzymatic (lactate dehydrogenase) method by measuring $\mathrm{OD}_{340 \mathrm{~nm}}$, and the content was determined by the standard curves [29].

\subsection{DNA Isolation and TaqMan Real-Time PCR Assay}

TaqMan real-time PCR was used to quantify the bacteria composition shifts at 2-day biofilms using a Premix Ex Taq (Probe qPCR). The species-specific primers and probes used for S. mutans, S. sanguinis and S. gordonii were designed following the methods described previously (Table 2) [8]. Conventional PCR was used to confirm the specificity of the primers. Biomass samples were collected, and total bacterial DNA isolation and purification were performed with the Genomic DNA Extraction Kit (TaKaRa Biotechnology Co., Ltd., Japan) following the manufacturer's protocol [8]. NanoDrop 2000 spectrophotometer (Thermo Scientific, Waltham, MA, USA) was used to determine the purity and concentration of the DNA. The absolute quantification was determined using Quant-Studio 3D Digital PCR System (Thermo Fisher Scientific) and analyzed with QuantStudio 3D AnalysisSuite Cloud Software (Thermo Fisher Scientific). The standard curves for quantification of the three bacterial species were generated by 10-fold dilutions of DNA extracted from the bacteria at $10^{8}$ CFUs to $10^{3}$ CFUs versus the logarithm of the concentration [44]. Based on the standard curves, the numbers of each strain on the disks were determined. 
Table 2. Primers and probes used in TaqMan qPCR.

\begin{tabular}{|c|c|c|c|c|}
\hline $\begin{array}{l}\text { Primer/ } \\
\text { Probes }\end{array}$ & Nucleotide Sequence & $\begin{array}{c}\text { Annealing } \\
\text { Temperature } \\
\left({ }^{\circ} \mathrm{C}\right)\end{array}$ & $\begin{array}{l}\text { Amplicon } \\
\text { Size (bp) }\end{array}$ & Reference \\
\hline \multicolumn{5}{|c|}{ Primers in TaqMan qPCR } \\
\hline S. mutans-f & 5' GCCTACAGCTCAGAGATGCTATTCT 3' & 59 & 114 & \multirow{2}{*}{ [45] } \\
\hline S. mutans-r & 5' GCCATACACCACTCATGAATTGA 3' & & & \\
\hline S. sanguinis-f & 5' GAGCGGATGGCCAATTATATCT 3' & 59 & 75 & \multirow{2}{*}{ [44] } \\
\hline S. sanguinis-r & 5' CCGGATGATGTCGGCAATA 3' & & & \\
\hline S. gordonii-f & 5' GGTGTTGTTTGACCCGTTCAG 3' & 59 & 96 & \multirow{2}{*}{ [46] } \\
\hline S. gordonii-r & 5' AGTCCATCCCACGAGCACAG 3' & & & \\
\hline \multicolumn{5}{|c|}{ Probes in TaqMan qPCR } \\
\hline S. mutans & 5' FAM-TGGAAATGACGGTCGCCGTTATGAA-TAMRA 3' & & & [45] \\
\hline S. sanguinis & 5' FAM-TGTTCGGGCTCATGATA-Eclipse 3' & & & [43] \\
\hline S. gordonii & 5' FAM-AACCTTGACCCGCTCATTACCAGCTAGTATG-TAMRA 3' & & & [46] \\
\hline
\end{tabular}

\subsection{Statistical Analysis}

Statistical analyses were performed using Statistical Package for the Social Sciences (SPSS 22.0, Chicago, IL, USA). All data were expressed as the mean value \pm standard deviation (mean \pm SD). One-way analyses of variance (ANOVA) were performed to detect the statistical significance of the variables. Tukey's multiple comparison test was used to compare the means of each of the groups. The differences in the means of data were considered significant if $p<0.05$.

\section{Results}

The load-bearing properties of the four composites (mean $\pm \mathrm{SD} ; n=6$ ) are presented in Figure 1. Compared to commercial control composite, the experimental composite control had significantly higher flexural strength and elastic modulus $(p<0.05)$, and the load-bearing capabilities were not negatively affected with the different mass fractions of DMAHDM $(p>0.1)$.
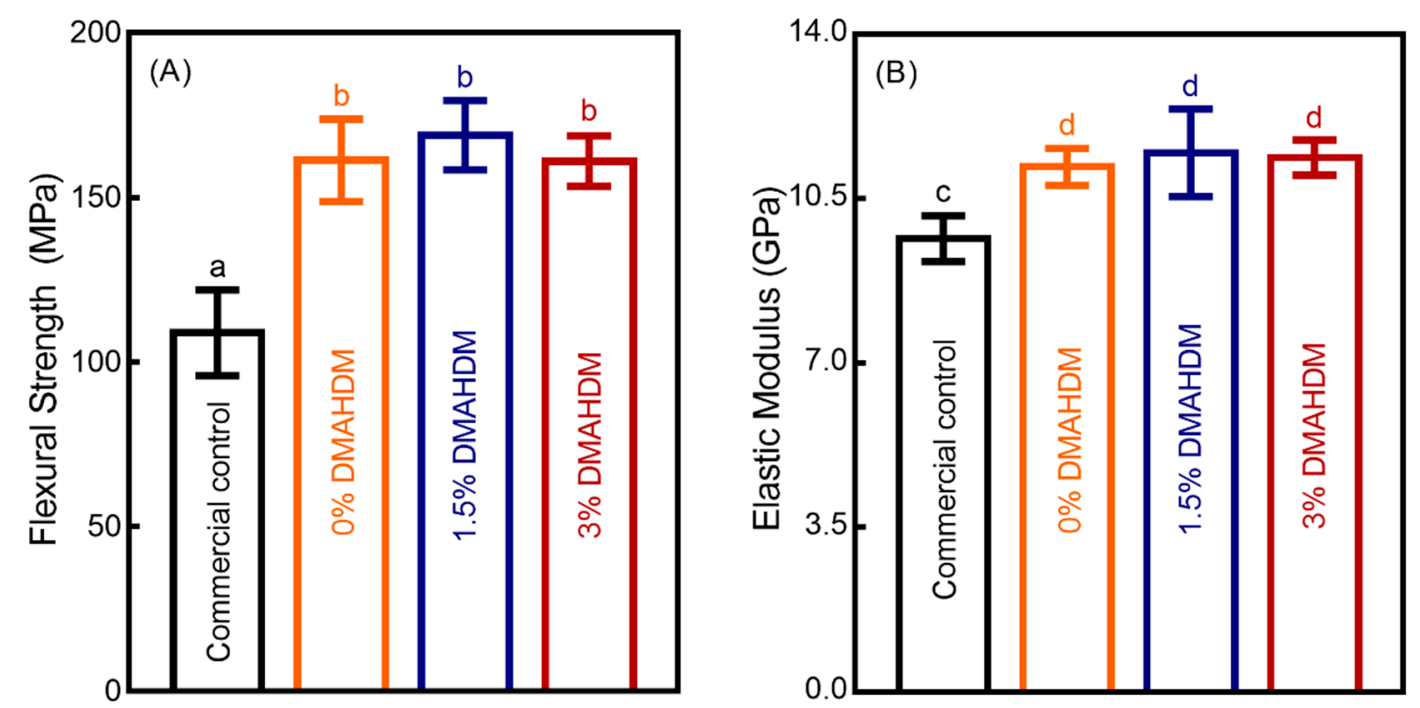

Figure 1. Mechanical properties of composites. (A) Flexural strength, and (B) elastic modulus (mean $\pm \mathrm{SD} ; n=6)$. Values with disparate letters $(\mathrm{a}, \mathrm{b}, \mathrm{c}, \mathrm{d})$ indicate data are significantly different $(p<0.05)$. 
Representative 2-day mature biofilm live/dead images are shown in Figure 2. The commercial control composite had mostly green staining of live bacteria. Composites with 0\% DMAHDM had similar images to commercial control. With the DMAHDM content increasing to 1.5\% (E, F), and 3\% $(\mathrm{G}, \mathrm{H})$, the amount of red staining of the compromised bacteria increased in the biofilms.
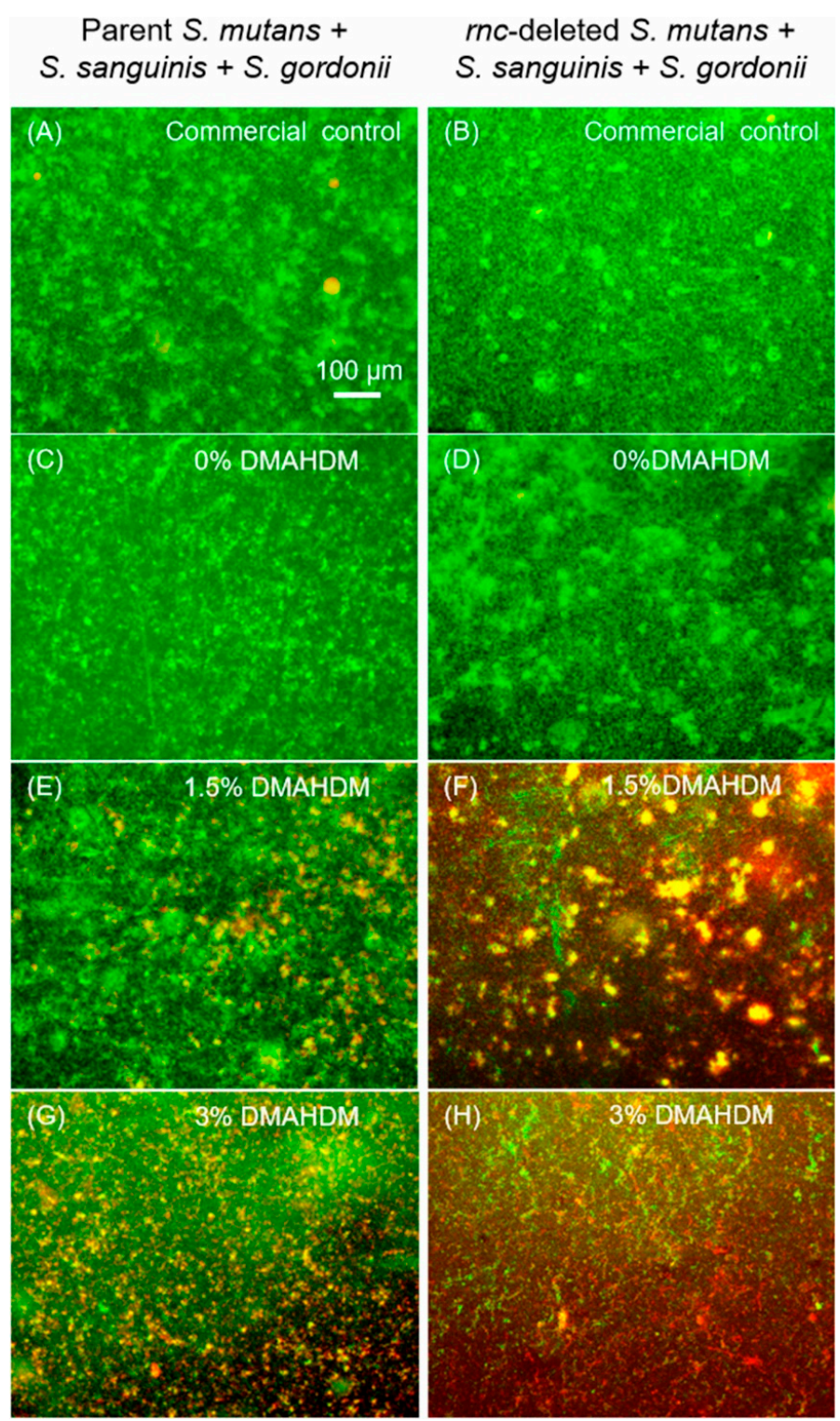

Figure 2. Representative live/dead staining images. Live/dead staining of 2-day $\mathrm{Sm}+\mathrm{Ss}+\mathrm{Sg}$ biofilms on composite: (A,B) Commercial control, (C,D) $0 \%$ dimethylaminohexadecyl methacrylate (DMAHDM), (E,F) 1.5\% DMAHDM, (G,H) 3\% DMAHDM. All images had the same magnification as (A). Live bacteria were stained green, and dead bacteria were stained red. When live and dead bacteria were close to each other or on the top of each other, resulting in yellowish or orange colors.

As shown in Figure 3A, the Sm $+\mathrm{Ss}+\mathrm{Sg}$ biofilm CFU counts of biofilms cultured for 2 days (mean $\pm \mathrm{SD} ; n=6)$ on DMAHDM composites were reduced with higher DMAHDM mass fraction $(p<0.05)$. Combining $r n c$ knockout for S. mutans with 3\% DMAHDM composite achieved the greatest biofilm inhibition. Compared to the control group, the CFUs of the rnc gene-knockout biofilms in $1.5 \%$ and $3 \%$ DMAHDM groups was reduced by about three logs and five logs, respectively $(p<0.05)$. Similarly, Figure 3B indicates that combining $r n c$ gene-knockout for $S$. mutans with DMAHDM composite led to the least biofilm metabolic activity $(p<0.05)$. 

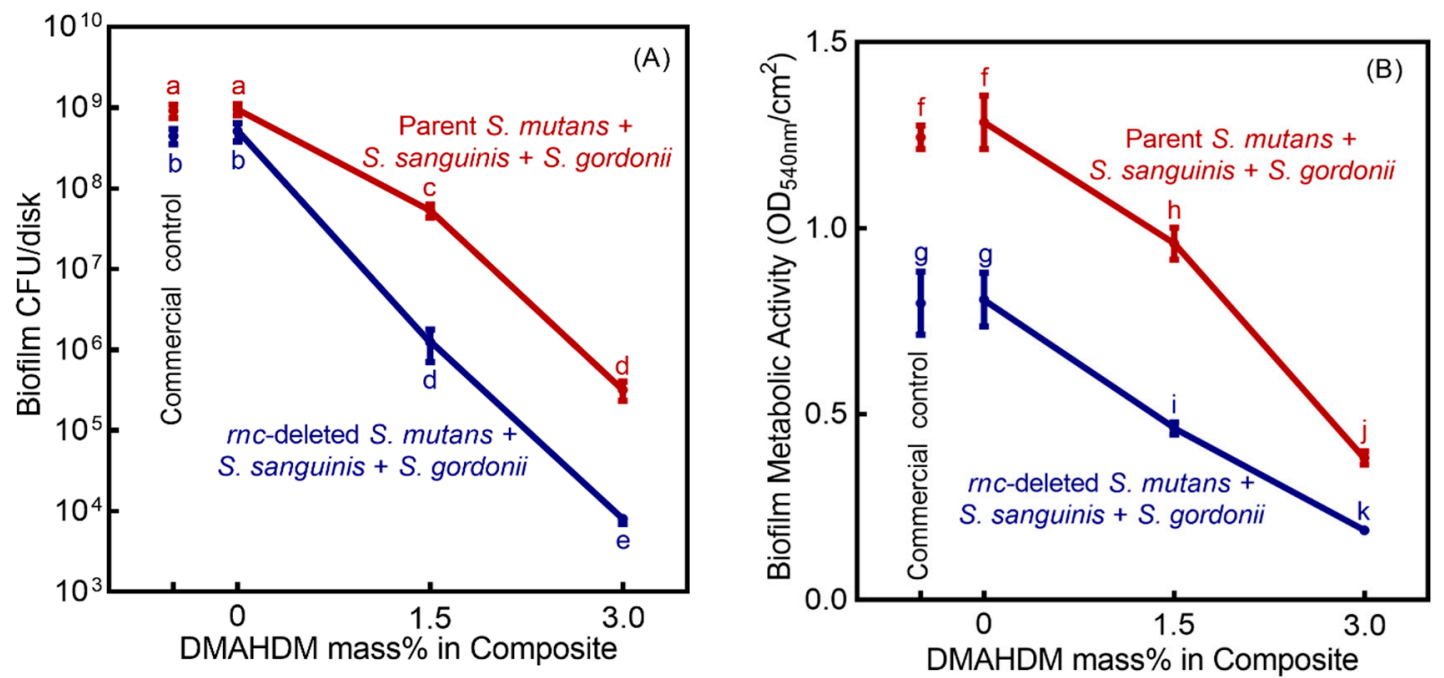

Figure 3. Antimicrobial effects of $r n c$ knockout for S. mutans plus DMAHDM composite (mean \pm SD; $n=6$ ). (A) Colony-forming units (CFUs), and (B) 3-(4,5-dimethylthiazol-2-yl)-2,5-diphenyl tetrazolium bromide (MTT) metabolic activity of $\mathrm{Sm}+\mathrm{Ss}+\mathrm{Sg}$ biofilms on composites. Values with disparate letters $(\mathrm{a}, \mathrm{b}, \mathrm{c}, \mathrm{d}, \mathrm{e}, \mathrm{f}, \mathrm{g}, \mathrm{h}, \mathrm{i}, \mathrm{j}, \mathrm{k})$ indicate data are significantly different $(p<0.05)$.

The standard curve of $\mathrm{OD}_{490 \mathrm{~nm}}$ against the polysaccharide content was expressed as $\mathrm{y}=0.0207 \mathrm{x}+$ 0.3082 , and the coefficient of determination $\left(R^{2}\right)$ was 0.9836 . A linear curve for the standard lactic acid (Supelco Analytical, Bellefonte, PA, USA) was obtained within the concentration range of 0-3.5 mM. The equation of the regression was $y=8.467 x-1.973$, and the coefficient of determination $\left(R^{2}\right)$ was 0.9942. In Figure 4A, the polysaccharide production of the 2-day Sm $+\mathrm{Ss}+\mathrm{Sg}$ biofilms on composites are plotted (mean $\pm \mathrm{SD} ; n=6$ ). Biofilm polysaccharide amount was greatly reduced with increasing DMAHDM mass fraction, compared to control composites $(p<0.05)$. In addition, the decreasing trend was more profound in biofilms with $r n c$-knockout $S$. mutans than that of parent $S$. mutans $(p<0.05)$. The lactic acid secretion (Figure 4B) was decreased with increasing DMAHDM mass fraction $(p<0.05)$. The combination of $r n c-k n o c k o u t$ in S. mutans with the 3\% DMAHDM composite led to the biggest decrease in lactic acid secretion by the $\mathrm{Sm}+\mathrm{Ss}+\mathrm{Sg}$ biofilms.
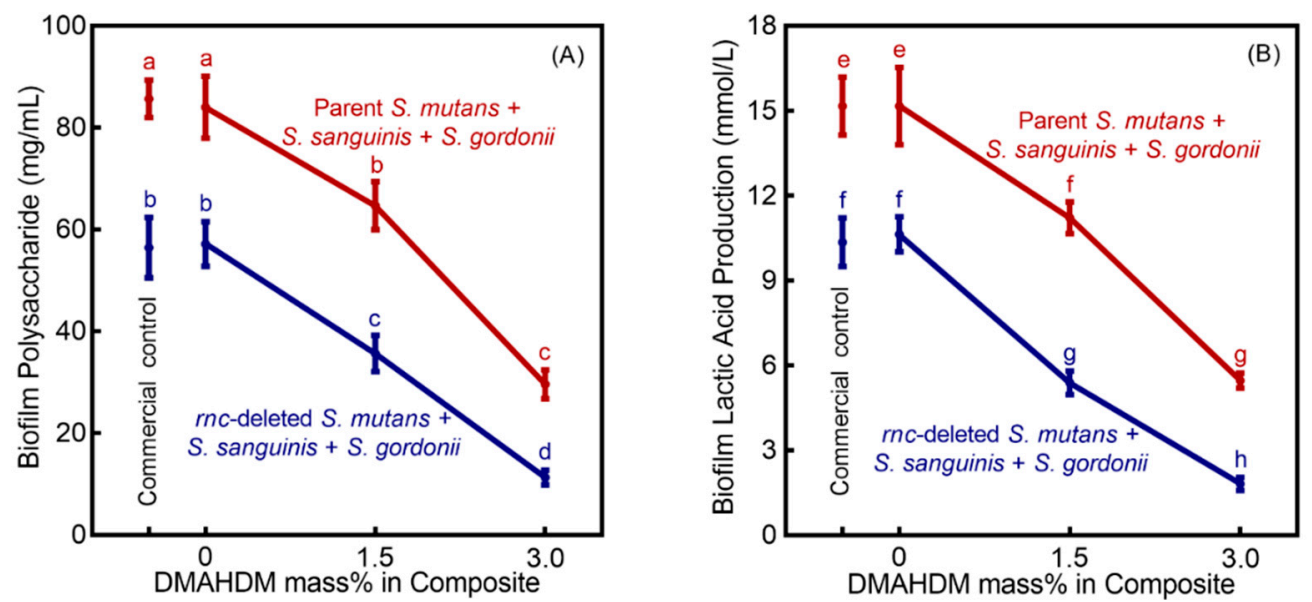

Figure 4. Inhibition effects of $r n c$ knockout for S. mutans plus DMAHDM composite against cariogenic activities of $\mathrm{Sm}+\mathrm{Ss}+\mathrm{Sg}$ biofilms (mean $\pm \mathrm{SD} ; n=6$ ). (A) Polysaccharide production by $\mathrm{Sm}+\mathrm{Ss}+$ $\mathrm{Sg}$ biofilms on composites. (B) Lactic acid secretion by $\mathrm{Sm}+\mathrm{Ss}+\mathrm{Sg}$ biofilms. Values with disparate letters $(\mathrm{a}, \mathrm{b}, \mathrm{c}, \mathrm{d}, \mathrm{e}, \mathrm{f}, \mathrm{g}, \mathrm{h})$ indicate data are significantly different $(p<0.05)$. 
Standard curves of $C_{t}$ value versus bacterial numbers of $S$. mutans, $S$. sanguinis and S. gordonii were constructed. The equation of the regression for $S$. mutans was $y=-3.3043 x+43.794$, and the coefficient of determination $\left(R^{2}\right)$ was 0.9997 . The equation of the regression for S. sanguinis was $y=-3.2962 x$ +48.733 , and the coefficient of determination $\left(R^{2}\right)$ was 0.9964 . The equation of the regression for S. gordonii was $y=-3.3246 x+48.305$, and the coefficient of determination $\left(R^{2}\right)$ was 0.9988 .

The TaqMan real-time PCR results demonstrated the ratio variation of bacteria in 2-day multispecies biofilms with different DMAHDM mass fractions (Figure 5) (mean $\pm \mathrm{SD} ; n=3$ ). With parent S. mutans, an overwhelming S. mutans proportion of $68.99 \%$ and $69.00 \%$ existed in the Sm + Ss + Sg biofilm on commercial control composite and $0 \%$ DMAHDM, respectively. In contrast, the patent $S$. mutans proportion decreased with increasing the mass fraction of DMAHDM, accounting for $36.67 \%$ in $1.5 \%$ DMHADM group, and $13.56 \%$ in 3\% DMHADM group.

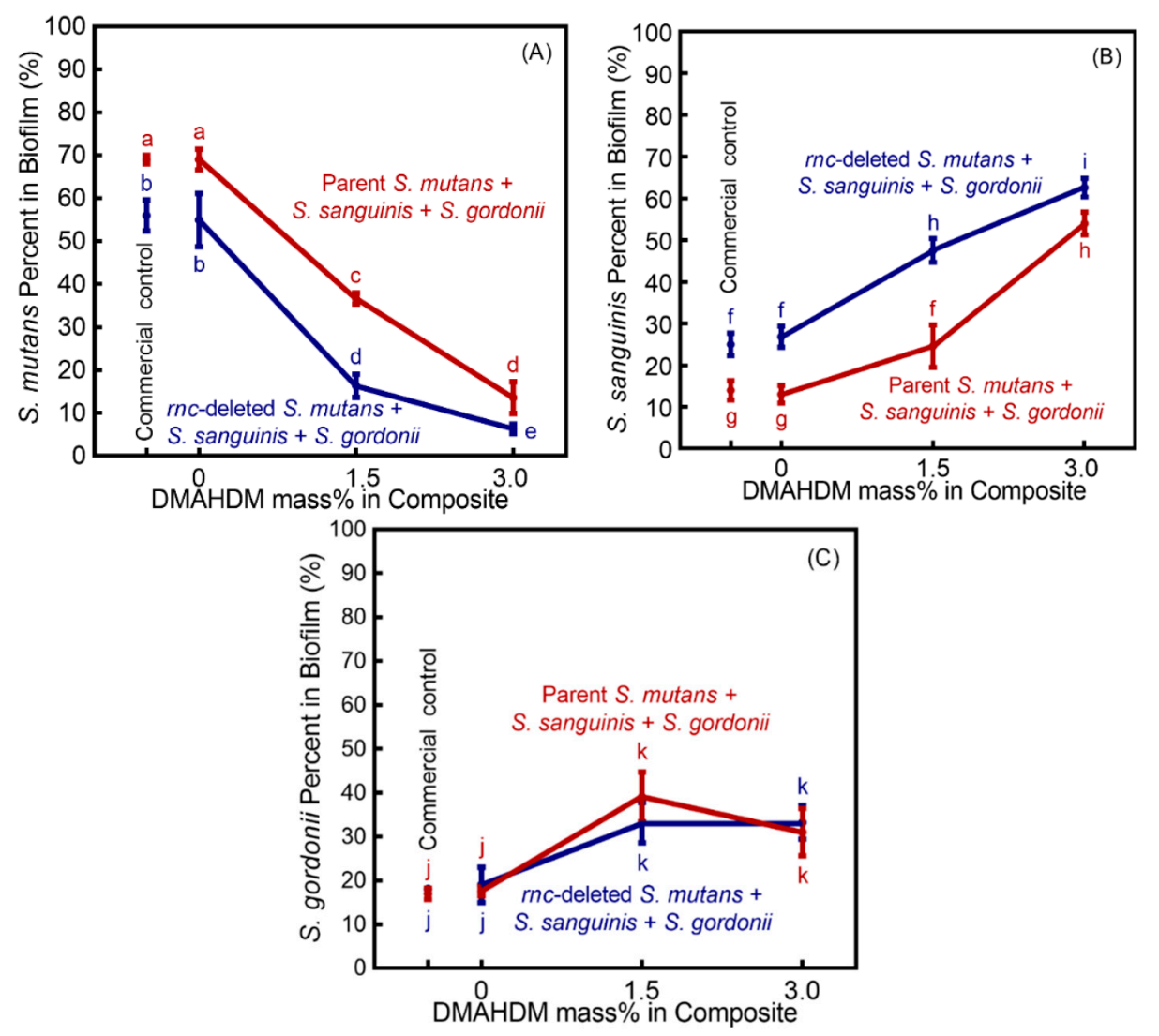

Figure 5. Bacterial species shift in $\mathrm{Sm}+\mathrm{Ss}+\mathrm{Sg}$ biofilm grown for 2 days on composites (mean $\pm \mathrm{SD} ; n=3$ ). (A) cariogenic S. mutans proportion, (B) non-cariogenic S. sanguinis proportion, and (C) non-cariogenic S. gordonii proportion. Cariogenic $S$. mutans had overwhelming proportions in commercial control and $0 \%$ DMAHDM group. However, with increasing DMAHDM mass fraction, the proportion of cariogenic S. mutans decreased sharply, whereas noncariogenic S. sanguinis and S. gordonii achieved a predominant proportion in the biofilms. Moreover, the effects of $r n c$ gene-knockout for $S$. mutans plus DMAHDM composite induce less $S$. mutans ratio. Values with disparate letters (a, b, c, d, e, f, g, h, i, j, k) indicate data are significantly different $(p<0.05)$.

Combining rnc-knockout for S. mutans with DMAHDM composite led to the biggest reduction in S. mutans percentage in the $\mathrm{Sm}+\mathrm{Ss}+\mathrm{Sg}$ biofilm. The fraction of rnc-knockout S. mutans decreased to $16.33 \%$ in the $1.5 \%$ DMHADM composite group, and to only $6.33 \%$ in the $3 \%$ DMHADM composite group. 
Figure 6 shows the influence of $r n c-k n o c k o u t$ for $S$. mutans alone, DMAHDM composite alone, and rnc-knockout for $S$. mutans plus DMAHDM composite, on bacterial composition shift of Sm $+\mathrm{Ss}+$ Sg biofilm: (A) The cariogenic S. mutans proportion, (B) non-cariogenic S. sanguinis proportion, and (C) lactic acid secretion (mean $\pm \mathrm{SD} ; n=6$ ). These results demonstrate that: (1) The rnc-knockout for $S$. mutans regulated the $\mathrm{Sm}+\mathrm{Ss}+\mathrm{Sg}$ biofilm species composition shift toward a healthier state and decreased the lactic acid secretion, even on composites without DMAHDM; (2) DMAHDM composite had the ability to regulate biofilm equilibrium and reduce the lactic acid secretion; (3) The combination of $r n c$-knockout in $S$. mutans with DMAHDM composite led to the biggest reduction in cariogenic S. mutans percentage in Sm $+\mathrm{Ss}+\mathrm{Sg}$ biofilm, gained the most substantial increase in non-cariogenic species percentage, yielding the least lactic acid secretion.

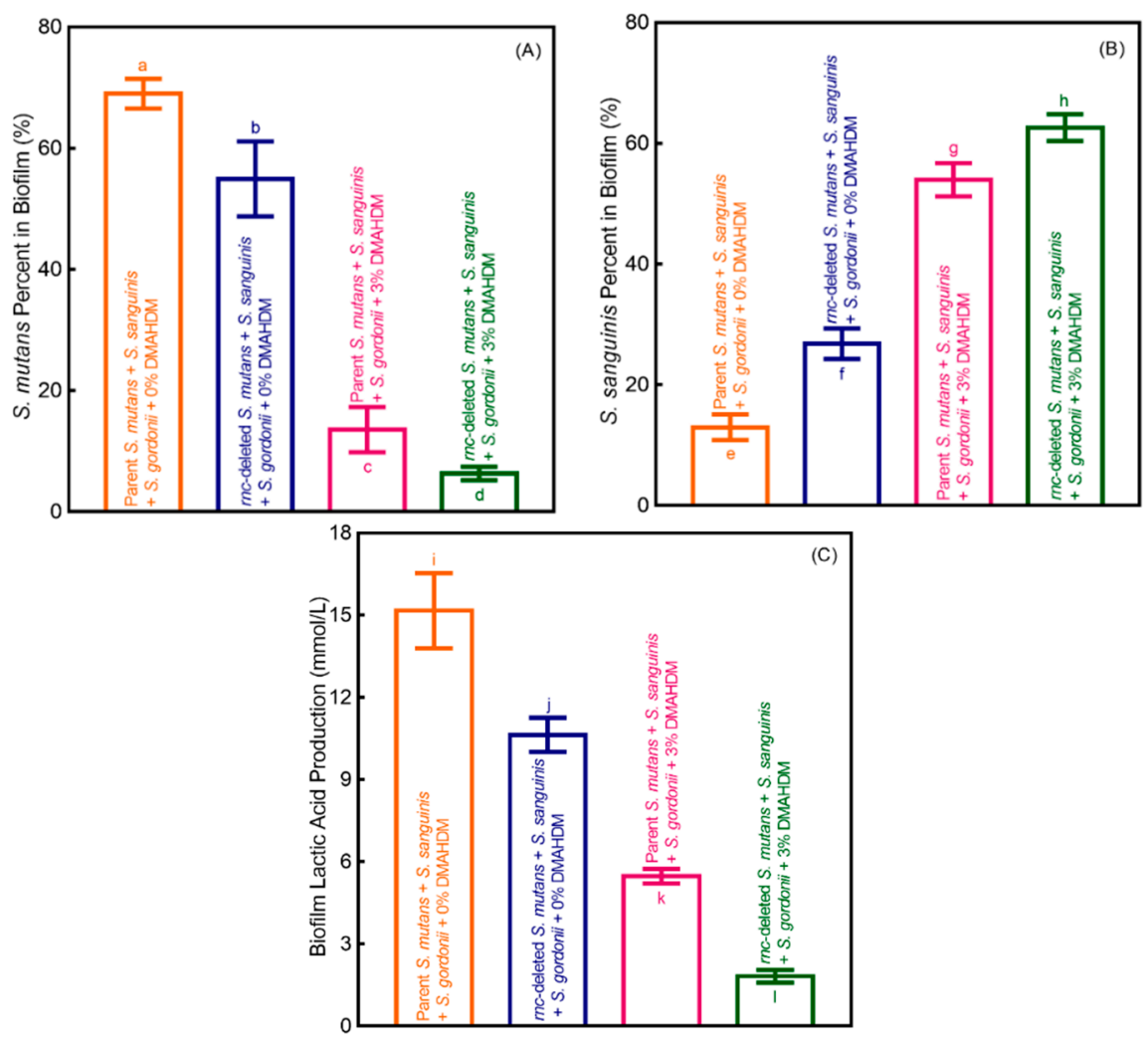

Figure 6. Effects of $r n c$-knockout alone, DMAHDM composite alone, the combination of $r n c$-knockout plus DMAHDM composite, on biofilm species shift and acid secretion. (A) Cariogenic S. mutans proportion, (B) noncariogenic S. sanguinis proportion, and (C) lactic acid secretion of $\mathrm{Sm}+\mathrm{Ss}+\mathrm{Sg}$ biofilm grown for 2 days on composites (mean $\pm \mathrm{SD} ; n=6$ ). In each plot, values with disparate letters $(\mathrm{a}, \mathrm{b}, \mathrm{c}, \mathrm{d}, \mathrm{e}, \mathrm{f}, \mathrm{g}, \mathrm{h}, \mathrm{i}, \mathrm{j}, \mathrm{k}, \mathrm{l})$ indicate data are significantly different $(p<0.05)$.

\section{Discussion}

This present study represents the first report on the effect of $r n c$ gene knockout in S. mutans on species proportional shift in a tri-species biofilm model, and furthermore, on the effect of combining S. mutans rnc knockout with DMAHDM composite in regulating the biofilm from a cariogenic state toward a non-cariogenic state. The $S$. mutans rnc gene-knockout alone significantly decreased the cariogenic S. mutans percentage in the $\mathrm{Sm}+\mathrm{Ss}+\mathrm{Sg}$ biofilm and increased the non-cariogenic species percentage. The DMAHDM composite alone caused a shift in biofilm species from a cariogenic composition toward a non-cariogenic composition. Most dramatically, by combining the rnc gene-knockout technology with the antimicrobial DMAHDM composite, the S. mutans percentage in the $\mathrm{Sm}+\mathrm{Ss}+\mathrm{Sg}$ biofilm was decreased from an overwhelming $69 \%$ of the parent $S$. mutans on control composite to only $6.3 \%$ of $r n c-k n o c k o u t S$. mutans on the 3\% DMAHDM composite. Meanwhile, 
the corresponding non-cariogenic S. sanguinis proportion in the $\mathrm{Sm}+\mathrm{Ss}+\mathrm{Sg}$ biofilm was increased from $12 \%$ to $61 \%$. Therefore, the dual strategy of $r n c-k n o c k o u t$ for $S$. mutans + DMAHDM composite is promising to be a viable method for regulating the biofilm composition to promote non-cariogenic species and suppress cariogenic species, thereby inhibiting biofilm acids and recurrent caries.

QAMs are promising for incorporation into composites, primers and adhesives due to their antimicrobial activity and low toxicity $[32,47,48]$. DMAHDM has a positively-charged quaternary amine $\mathrm{N}^{+}$and a long alkyl chain with a chain length of $16[49,50] . \mathrm{N}^{+}$can contact the negatively-charged cell membrane of bacteria and alter the electric balance, leading the bacteria to explode under its own osmotic pressure $[49,50]$. Meanwhile, the long cationic polymers can penetrate bacterial cells by disrupting the membranes $[8,49]$. DMAHDM can be co-polymerized and covalently bonded in resins to provide long-term contact-inhibition against bacteria $[49,50]$. This study showed that the incorporation of 3\% DMAHDM into the composite did not negatively affect the flexural strength and the elastic modulus as compared to those of commercial control composite and 0\% DMAHDM.

Interactions within oral microbial communities are major factors affecting the development of biofilm, and the cariogenic potential of the oral microbial consortia depends on the environmental conditions and the composition of the bacterial flora [44,51]. For a better representation of oral microorganisms, an Sm + Ss + Sg biofilm model was used to include S. mutans, S. sanguinis and $S$. gordonii $[7,8,44]$. As a key modulator, $S$. mutans is the primary exopolysaccharides (EPS) producer in the oral cavity and is responsible for dental caries [14,15]. The acidification of the EPS-rich matrix favors the growth of the cariogenic pathogens, promotes demineralization of the enamel apatite on the teeth, and leads to the onset of dental caries [52,53]. Although S. mutans is an important player in caries pathogenesis, its role in caries is not etiological [54]. The correlation between caries experience with elevated numbers of $S$. mutans has been controversial and not well-established [54-56]. Some studies demonstrated a real association between $S$. mutans and the carious lesion, whereas other studies revealed no clear association [57]. In some studies, caries lesions occurred without the presence of S. mutans [58].

Oral streptococci account for $20 \%$ of all supragingival microorganisms, but they account for nearly $80 \%$ of the initial colonizers during the early stages of biofilm formation [56]. Furthermore, oral streptococci have been associated with the onset and progression of carious lesions [8,56]. When being present in the oral biofilm in high numbers, the pioneer colonizers S. sanguinis and S. gordonii can antagonize $S$. mutans [59]. According to clinical studies, a great percentage of $S$. mutans was always found in the caries lesion, which indicated its acidogenicity and cariogenicity $[8,60,61]$. In contrast, higher percentages of S. sanguinis and S. gordonii in dental plaque were associated with sound tooth surfaces without caries [8,60,61].

The exopolysaccharides (EPS) matrix is a key virulence factor. It serves as nutrients and helps form the core of the matrix scaffold [52]. In addition, the EPS matrix does contribute towards drug resistance which can be a diffusion barrier to stop the antimicrobial agents [53]. Previous studies indicated that targeting the biofilm EPS matrix may be an effective strategy for removing biofilms, killing bacteria and disrupting the pathogenic environment [62]. In the present study, the rnc knockout for S. mutans disrupted the polysaccharide synthesis in the $\mathrm{Sm}+\mathrm{Ss}+\mathrm{Sg}$ biofilm. The fewer polysaccharides indicated an easier exposure to antimicrobial agents [63]. Therefore, the rnc knockout for S. mutans reduced the virulence factor and rendered the biofilm to become more sensitive to DMAHDM composite. This synergistic effect from the combination of $r n c-k n o c k o u t$ for $S$. mutans with DMAHDM composite achieved the greatest biofilm-inhibition efficacy, reducing biofilm CFUs by five logs.

Biofilms can produce organic acids, lower the $\mathrm{pH}$, and induce the selection for an acidogenic and aciduric flora, thus shifting the biofilm composition from a healthy state to a cariogenic state [8]. In the present study, the lactic acid secretion by biofilms decreased significantly on DMAHDM-containing composite, especially at the mass fraction of 3\%. Moreover, the combination rnc-knockout for S. mutans with the 3\% DMAHDM composite achieved the greatest reduction in the lactic acid secretion of the $\mathrm{Sm}+\mathrm{Ss}+\mathrm{Sg}$ biofilm by an order of magnitude. The substantial reduction in acid secretion 
helped the non-cariogenic species to survive and grow, thus maintaining a healthy non-cariogenic biofilm composition.

Indeed, the combined contribution of rnc knockout in S. mutans and DMAHDM composite on biofilm modulation was remarkable. With only $6.3 \% \mathrm{~S}$. mutans in the biofilm, the non-cariogenic species can grow and thrive. Therefore, $r n c$ knockout in S. mutans plus DMAHDM composite demonstrated the ability to bring the biofilm species balance back toward a healthy state for the first time. This percentage shift of bacteria was attributed to the dual pressure of both the competition among bacteria and the antimicrobial agent. This was because: (1) the antimicrobial effect from DMAHDM exerted an acid-inhibition effect to weaken the competitiveness of S. mutans in the Sm + Ss + Sg biofilm; (2) $r n c$ knockout for S. mutans produced less polysaccharide in $\mathrm{Sm}+\mathrm{Ss}+\mathrm{Sg}$ biofilm models which decreased the biofilm drug-tolerance and induced greater sensitivity to DMAHDM; (3) S. mutans $r n c-k n o c k o u t$ plus DMAHDM composite achieved the greatest reduction in lactic acid secretion, which helped the non-cariogenic and non-aciduric species to survive and grow $[8,12]$. Therefore, the use of $r n c$ gene-knockout in S. mutans plus the bioactive and therapeutic composite caused the greatest decrease in biofilm acid secretion, which provided an environment in favor of the non-cariogenic species, which would be clinically beneficial to prevent caries. A previous study [64] reported a unique method of probiotic bacterial colonization to prevent tooth decay. In addition, further study is still needed to investigate the $S$. mutans $r n c$ gene-knockout effect in an oral biofilm model in vivo with animal experiments. Further studies are needed to investigate the dual strategy of $r n c$ gene-knockout in S. mutans plus DMAHDM in regulating biofilm development tendency to a healthy composition by testing more species to mimic the complexity of oral biofilms.

\section{Conclusions}

This study demonstrated the high efficacy of $r n c$ gene knockout in S. mutans and a bioactive and therapeutic composite in $\mathrm{Sm}+\mathrm{Ss}+\mathrm{Sg}$ biofilm modulation to suppress the cariogenic species percentage and increase the non-cariogenic species percentage for the first time. The $S$. mutans rnc gene-knockout alone reduced the cariogenic $S$. mutans percentage in the $\mathrm{Sm}+\mathrm{Ss}+\mathrm{Sg}$ biofilm. The DMAHDM composite induced a shift in biofilm species from a cariogenic composition toward a non-cariogenic composition. The dual strategy of combining $r n c$ gene-knockout with DMAHDM composite yielded the greatest reduction in S. mutans percentage in the $\mathrm{Sm}+\mathrm{Ss}+\mathrm{Sg}$ biofilm, and the greatest increase in the non-cariogenic species percentage, thereby resulting in the lowest amount of biofilm acid. The dual strategy reduced the cariogenic S. mutans proportion from $69 \%$ on commercial composite, to $6 \%$ on $3 \%$ DMAHDM. Combining the $r n c$ knockout for S. mutans with DMAHDM composite reduced the biofilm CFUs by five logs. Therefore, the novel dual strategy of bacterial gene-modification and bioactive and therapeutic dental resin has the potential to modulate biofilm shift from a cariogenic state to a non-cariogenic state. This novel dual strategy is promising for a wide range of applications in preventive and restorative dentistry.

Author Contributions: Conceptualization, T.H., K.Z. and H.H.K.X.; Methodology, T.H., H.H.K.X., M.D.W., H.C., Q.D. and K.Y.; Investigation, H.C., T.H., Y.Y. and H.H.K.X.; Analysis and Graphs-T.H., N.H. and T.W.O.; Writing-H.C., T.H., Y.Y. and H.H.K.X.; Writing—Review \& Editing, H.H.K.X., H.C., and K.Z.; Funding Acquisition, H.H.K.X., Y.Y., K.Y., and K.Z.; Resources, L.L., K.Z., M.D.W. and T.W.O.; Supervision, M.D.W. and T.W.O.; Project Administration, H.H.K.X. and T.H. All authors have read and agreed to the published version of the manuscript

Funding: This study was supported by National Natural Science Foundation of China (NSFC) 81771068 (Y.Y.), grants from Applied basic research of Sichuan Province 2018JY0580 (Y.Y.), Capital's Funds for Health Improvement and Research CFH2020-2-2142 (K.Z.), Beijing Hospitals Authority Ascent Plan DFL20191501 (K.Y.), a seed grant from the University of Maryland Baltimore (H.H.K.X.), and a bridge grant from the University of Maryland School of Dentistry (H.H.K.X.).

Acknowledgments: We gratefully thank Esstech and Dentsply for donating the materials, and Laurence C. Chow, Joseph M. Antonucci and Nancy J. Lin for discussions.

Conflicts of Interest: The authors declare no conflict of interest. 


\section{References}

1. Human Microbiome Project Consortium. Structure, function and diversity of the healthy human microbiome. Nature 2012, 486, 207. [CrossRef] [PubMed]

2. Inquimbert, C.; Bourgeois, D.; Bravo, M.; Viennot, S.; Tramini, P.; Llodra, J.C.; Molinari, N.; Dussart, C.; Giraudeau, N.; Carrouel, F. The oral bacterial microbiome of interdental surfaces in adolescents according to carious risk. Microorganisms 2019, 7, 319. [CrossRef] [PubMed]

3. Bourgeois, D.; David, A.; Inquimbert, C.; Tramini, P.; Molinari, N.; Carrouel, F. Quantification of carious pathogens in the interdental microbiota of young caries-free adults. PLoS ONE 2017, 12, e0185804. [CrossRef] [PubMed]

4. Gao, L.; Xu, T.; Huang, G.; Jiang, S.; Gu, Y.; Chen, F. Oral microbiomes: More and more importance in oral cavity and whole body. Protein Cell 2018, 9, 488-500. [CrossRef] [PubMed]

5. Su, Y.; Chen, C.; Guo, L.; Du, J.; Li, X.; Liu, Y. Ecological balance of oral microbiota is required to maintain oral mesenchymal stem cell homeostasis. Stem Cells 2018, 36, 551-561. [CrossRef]

6. Kilian, M.; Chapple, I.; Hannig, M.; Marsh, P.; Meuric, V.; Pedersen, A.; Tonetti, M.; Wade, W.; Zaura, E. The oral microbiome-an update for oral healthcare professionals. Br. Dent. J. 2016, 221, 657-666. [CrossRef]

7. Zhou, Y.; Wang, S.; Zhou, X.; Zou, Y.; Li, M.; Peng, X.; Ren, B.; Xu, H.H.; Weir, M.D.; Cheng, L. Short-time antibacterial effects of dimethylaminododecyl methacrylate on oral multispecies biofilm in vitro. Biomed Res. Int. 2019, 2019, 6393470. [CrossRef]

8. Wang, H.; Wang, S.; Cheng, L.; Jiang, Y.; Melo, M.A.S.; Weir, M.D.; Oates, T.W.; Zhou, X.; Xu, H.H. Novel dental composite with capability to suppress cariogenic species and promote non-cariogenic species in oral biofilms. Mater. Sci. Eng. C Mater. Biol. Appl. 2019, 94, 587-596. [CrossRef]

9. Lynch, C.D.; Frazier, K.B.; McConnell, R.J.; Blum, I.R.; Wilson, N.H. Minimally invasive management of dental caries: Contemporary teaching of posterior resin-based composite placement in US and Canadian dental schools. J. Am. Dent. Assoc. 2011, 142, 612-620. [CrossRef]

10. Marsh, P.D.; Head, D.A.; Devine, D.A. Dental plaque as a biofilm and a microbial community-Implications for treatment. J. Oral. Biosci. 2015, 57, 185-191. [CrossRef]

11. Kreth, J.; Merritt, J.; Qi, F. Bacterial and host interactions of oral streptococci. DNA Cell Biol. 2009, 28, $397-403$. [CrossRef] [PubMed]

12. Kreth, J.; Zhang, Y.; Herzberg, M.C. Streptococcal antagonism in oral biofilms: Streptococcus sanguinis and Streptococcus gordonii interference with Streptococcus mutans. J. Bacteriol. 2008, 190, 4632-4640. [CrossRef] [PubMed]

13. Nobbs, A.H.; Zhang, Y.; Khammanivong, A.; Herzberg, M.C. Streptococcus gordonii Hsa environmentally constrains competitive binding by Streptococcus sanguinis to saliva-coated hydroxyapatite. J. Bacteriol. 2007, 189, 3106-3114. [CrossRef] [PubMed]

14. Huang, X.; Browngardt, C.M.; Jiang, M.; Ahn, S.-J.; Burne, R.A.; Nascimento, M.M. Diversity in antagonistic interactions between commensal oral streptococci and Streptococcus mutans. Caries Res. 2018, 52, 88-101. [CrossRef] [PubMed]

15. Pitts, N.B.; Zero, D.T.; Marsh, P.D.; Ekstrand, K.; Weintraub, J.A.; Ramos-Gomez, F.; Tagami, J.; Twetman, S.; Tsakos, G.; Ismail, A. Dental caries. Nat. Rev. Dis. Primers 2017, 3, 1-16. [CrossRef]

16. Beazoglou, T.; Eklund, S.; Heffley, D.; Meiers, J.; Brown, L.J.; Bailit, H. Economic impact of regulating the use of amalgam restorations. Public Health Rep. 2007, 122, 657-663. [CrossRef]

17. Vallittu, P.K.; Boccaccini, A.R.; Hupa, L.; Watts, D.C. Bioactive dental materials-Do they exist and what does bioactivity mean? Dent. Mater. 2018, 34, 693. [CrossRef]

18. Demarco, F.F.; Corrêaa, M.B.; Cenci, M.S.; Moraes, R.R.; Opdam, N.J. Longevity of posterior composite restorations: Not only a matter of materials. Dent. Mater. 2012, 28, 87-101. [CrossRef]

19. Wang, X.; Huyang, G.; Palagummi, S.V.; Liu, X.; Skrtic, D.; Beauchamp, C.; Bowen, R.; Sun, J. High performance dental resin composites with hydrolytically stable monomers. Dent. Mater. 2018, 34, 228-237. [CrossRef]

20. Ferracane, J.L. Resin-based composite performance: Are there some things we can't predict? Dent. Mater. 2013, 29, 51-58. [CrossRef] 
21. Jiao, Y.; Niu, L.-n.; Ma, S.; Li, J.; Tay, F.R.; Chen, J.-h. Quaternary ammonium-based biomedical materials: State-of-the-art, toxicological aspects and antimicrobial resistance. Prog. Polym. Sci. 2017, 71, 53-90. [CrossRef] [PubMed]

22. Jiang, Y.-L.; Qiu, W.; Zhou, X.-D.; Li, H.; Lu, J.-Z.; Xu, H.H.; Peng, X.; Li, M.-Y.; Feng, M.-Y.; Cheng, L. Quaternary ammonium-induced multidrug tolerant Streptococcus mutans persisters elevate cariogenic virulence in vitro. Int. J. Oral Sci. 2017, 9, e7. [CrossRef]

23. Zhang, N.; Zhang, K.; Melo, M.A.; Weir, M.D.; Xu, D.J.; Bai, Y.; Xu, H.H. Effects of long-term water-aging on novel anti-biofilm and protein-repellent dental composite. Int. J. Mol. Sci. 2017, 18, 186. [CrossRef] [PubMed]

24. Imazato, S.; Torii, M.; Tsuchitani, Y.; McCabe, J.; Russell, R. Incorporation of bacterial inhibitor into resin composite. J. Dent. Res. 1994, 73, 1437-1443. [CrossRef]

25. Cheng, L.; Weir, M.D.; Xu, H.H.; Antonucci, J.M.; Kraigsley, A.M.; Lin, N.J.; Lin-Gibson, S.; Zhou, X. Antibacterial amorphous calcium phosphate nanocomposites with a quaternary ammonium dimethacrylate and silver nanoparticles. Dent. Mater. 2012, 28, 561-572. [CrossRef]

26. Beyth, N.; Yudovin-Farber, I.; Perez-Davidi, M.; Domb, A.J.; Weiss, E.I. Polyethyleneimine nanoparticles incorporated into resin composite cause cell death and trigger biofilm stress in vivo. Proc. Natl. Acad. Sci. USA 2010, 107, 22038-22043. [CrossRef]

27. Pietrokovski, Y.; Nisimov, I.; Kesler-Shvero, D.; Zaltsman, N.; Beyth, N. Antibacterial effect of composite resin foundation material incorporating quaternary ammonium polyethyleneimine nanoparticles. J. Prosthet. Dent. 2016, 116, 603-609. [CrossRef]

28. Ma, S.; Izutani, N.; Imazato, S.; Chen, J.-H.; Kiba, W.; Yoshikawa, R.; Takeda, K.; Kitagawa, H.; Ebisu, S. Assessment of bactericidal effects of quaternary ammonium-based antibacterial monomers in combination with colloidal platinum nanoparticles. Dent. Mater. J. 2012, 31, 150-156. [CrossRef]

29. Cheng, L.; Weir, M.D.; Zhang, K.; Wu, E.J.; Xu, S.M.; Zhou, X.; Xu, H.H. Dental plaque microcosm biofilm behavior on calcium phosphate nanocomposite with quaternary ammonium. Dent. Mater. 2012, 28, 853-862. [CrossRef]

30. Wang, S.; Wang, H.; Ren, B.; Li, X.; Wang, L.; Zhou, H.; Weir, M.D.; Zhou, X.; Masri, R.M.; Oates, T.W. Drug resistance of oral bacteria to new antibacterial dental monomer dimethylaminohexadecyl methacrylate. Sci. Rep. 2018, 8, 1-11. [CrossRef]

31. Zhou, H.; Li, F.; Weir, M.D.; Xu, H.H. Dental plaque microcosm response to bonding agents containing quaternary ammonium methacrylates with diffferent chain lengths and charge densities. J. Dent. 2013, 41, 1122-1131. [CrossRef] [PubMed]

32. Baras, B.H.; Melo, M.A.S.; Thumbigere-Math, V.; Tay, F.R.; Fouad, A.F.; Oates, T.W.; Weir, M.D.; Cheng, L.; $\mathrm{Xu}, \mathrm{H} . \mathrm{H}$. Novel bioactive and therapeutic root canal sealers with antibacterial and remineralization properties. Materials 2020, 13, 1096. [CrossRef] [PubMed]

33. Mao, M.-Y.; Yang, Y.-M.; Li, K.-Z.; Lei, L.; Li, M.; Yang, Y.; Tao, X.; Yin, J.-X.; Zhang, R.; Ma, X.-R.; et al. The rnc gene promotes exopolysaccharide synthesis and represses the vicRKX gene expressions via microRNA-size small RNAs in Streptococcus mutans. Front. Microbiol. 2016, 7, 687. [CrossRef] [PubMed]

34. Koo, H.; Allan, R.N.; Howlin, R.P.; Stoodley, P.; Hall-Stoodley, L. Targeting microbial biofilms: Current and prospective therapeutic strategies. Nat. Rev. Microbiol. 2017, 15, 740. [CrossRef]

35. Chen, H.; Zhang, B.; Weir, M.D.; Homayounfar, N.; Fay, G.G.; Martinho, F.; Lei, L.; Bai, Y.; Hu, T.; Xu, H.H. mutans gene-modification and antibacterial resin composite as dual strategy to suppress biofilm acid production and inhibit caries. J. Dent. 2020, 93, 103278. [CrossRef] [PubMed]

36. Chen, H.; Tang, Y.; Weir, M.D.; Gao, J.; Imazato, S.; Oates, T.W.; Lei, L.; Wang, S.; Hu, T.; Xu, H.H. Effects of S. mutans gene-modification and antibacterial monomer dimethylaminohexadecyl methacrylate on biofilm growth and acid production. Dent. Mater. 2020, 36, 296-309. [CrossRef]

37. Antonucci, J.M.; Zeiger, D.N.; Tang, K.; Lin-Gibson, S.; Fowler, B.O.; Lin, N.J. Synthesis and characterization of dimethacrylates containing quaternary ammonium functionalities for dental applications. Dent. Mater. 2012, 28, 219-228. [CrossRef]

38. Li, F.; Weir, M.D.; Fouad, A.F.; Xu, H.H. Time-kill behaviour against eight bacterial species and cytotoxicity of antibacterial monomers. J. Dent. 2013, 41, 881-891. [CrossRef] 
39. Sun, J.; Forster, A.M.; Johnson, P.M.; Eidelman, N.; Quinn, G.; Schumacher, G.; Zhang, X.; Wu, W.-1. Improving performance of dental resins by adding titanium dioxide nanoparticles. Dent. Mater. 2011, 27, 972-982. [CrossRef]

40. Wang, L.; Xie, X.; Imazato, S.; Weir, M.D.; Reynolds, M.A.; Xu, H.H. A protein-repellent and antibacterial nanocomposite for Class-V restorations to inhibit periodontitis-related pathogens. Mater. Sci. Eng. C Mater. Biol. Appl. 2016, 67, 702-710. [CrossRef]

41. Moreau, J.L.; Sun, L.; Chow, L.C.; Xu, H.H. Mechanical and acid neutralizing properties and bacteria inhibition of amorphous calcium phosphate dental nanocomposite. J. Biomed. Mater. Res. B Appl. Biomater. 2011, 98, 80-88. [CrossRef] [PubMed]

42. Xu, X.; Ling, L.; Wang, R.; Burgess, J.O. Formulation and characterization of a novel fluoride-releasing dental composite. Dent. Mater. 2006, 22, 1014-1023. [CrossRef]

43. Fteita, D.; Könönen, E.; Söderling, E.; Gürsoy, U.K. Effect of estradiol on planktonic growth, coaggregation, and biofilm formation of the Prevotella intermedia group bacteria. Anaerobe 2014, 27, 7-13. [CrossRef] [PubMed]

44. Zhang, K.; Wang, S.; Zhou, X.; Xu, H.; Weir, M.; Ge, Y.; Li, M.; Wang, S.; Li, Y.; Xu, X. Effect of antibacterial dental adhesive on multispecies biofilms formation. J. Dent. Res. 2015, 94, 622-629. [CrossRef] [PubMed]

45. Yoshida, A.; Suzuki, N.; Nakano, Y.; Kawada, M.; Oho, T.; Koga, T. Development of a $5^{\prime}$ nuclease-based real-time PCR assay for quantitative detection of cariogenic dental pathogens Streptococcus mutans and Streptococcus sobrinus. J. Clin. Microbiol. 2003, 41, 4438-4441. [CrossRef]

46. Suzuki, N.; Nakano, Y.; Yoshida, A.; Yamashita, Y.; Kiyoura, Y. Real-time TaqMan PCR for quantifying oral bacteria during biofilm formation. J. Clin. Microbiol. 2004, 42, 3827-3830. [CrossRef]

47. Lynch, C.D.; Opdam, N.J.; Hickel, R.; Brunton, P.A.; Gurgan, S.; Kakaboura, A.; Shearer, A.C.; Vanherle, G.; Wilson, N.H. Guidance on posterior resin composites: Academy of operative dentistry-European section. J. Dent. 2014, 42, 377-383. [CrossRef]

48. Ferracane, J.L. Resin composite-State of the art. Dent. Mater. 2011, 27, 29-38. [CrossRef]

49. Ge, Y.; Wang, S.; Zhou, X.; Wang, H.; Xu, H.H.; Cheng, L. The use of quaternary ammonium to combat dental caries. Materials 2015, 8, 3532-3549. [CrossRef]

50. Wu, J.; Zhou, C.; Ruan, J.; Weir, M.D.; Tay, F.; Sun, J.; Melo, M.A.S.; Oates, T.W.; Chang, X.; Xu, H.H. Self-healing adhesive with antibacterial activity in water-aging for 12 months. Dent. Mater. 2019, 35, 1104-1116. [CrossRef]

51. Daood, D.; Yiu, C.; Burrow, M.; Niu, L.-N.; Tay, F. Effect of a novel quaternary ammonium silane cavity disinfectant on durability of resin-dentine bond. J. Dent. 2017, 60, 77-86. [CrossRef]

52. Cugini, C.; Shanmugam, M.; Landge, N.; Ramasubbu, N. The role of exopolysaccharides in oral biofilms. J. Dent. Res. 2019, 98, 739-745. [CrossRef] [PubMed]

53. Koo, H.; Xiao, J.; Klein, M.I. Extracellular polysaccharides matrix-an often forgotten virulence factor in oral biofilm research. Int. J. Oral Sci. 2009, 1, 229. [CrossRef] [PubMed]

54. Kleinberg, I. A mixed-bacteria ecological approach to understanding the role of the oral bacteria in dental caries causation: An alternative to Streptococcus mutans and the specific-plaque hypothesis. Crit. Rev. Oral Biol. Med. 2002, 13, 108-125. [CrossRef] [PubMed]

55. Giacaman, R.A.; Torres, S.; Gómez, Y.; Muñoz-Sandoval, C.; Kreth, J. Correlation of Streptococcus mutans and Streptococcus sanguinis colonization and ex vivo hydrogen peroxide production in carious lesion-free and high caries adults. Arch. Oral Biol. 2015, 60, 154-159. [CrossRef] [PubMed]

56. Lemos, J.A.; Abranches, J.; Burne, R.A. Responses of cariogenic streptococci to environmental stresses. Curr. Issues Mol. Biol. 2005, 7, 95-107.

57. Köhler, B.; Bjarnason, S. Mutans streptococci, lactobacilli and caries prevalence in 15 to 16 -year olds in Göteborg. Part II. Swed. Dent. J. 1992, 16, 253-259.

58. Johansson, I.; Witkowska, E.; Kaveh, B.; Lif Holgerson, P.; Tanner, A.C.R. The microbiome in populations with a low and high prevalence of caries. J. Dent. Res. 2016, 95, 80-86. [CrossRef]

59. Becker, M.R.; Paster, B.J.; Leys, E.J.; Moeschberger, M.L.; Kenyon, S.G.; Galvin, J.L.; Boches, S.K.; Dewhirst, F.E.; Griffen, A.L. Molecular analysis of bacterial species associated with childhood caries. J. Clin. Microbiol. 2002, 40, 1001-1009. [CrossRef]

60. Ge, Y.; Caufield, P.; Fisch, G.; Li, Y. Streptococcus mutans and Streptococcus sanguinis colonization correlated with caries experience in children. Caries Res. 2008, 42, 444-448. [CrossRef] 
61. Marchant, S.; Brailsford, S.; Twomey, A.; Roberts, G.; Beighton, D. The predominant microflora of nursing caries lesions. Caries Res. 2001, 35, 397-406. [CrossRef] [PubMed]

62. Hobley, L.; Harkins, C.; MacPhee, C.E.; Stanley-Wall, N.R. Giving structure to the biofilm matrix: An overview of individual strategies and emerging common themes. FEMS Microbiol. Rev. 2015, 39, 649-669. [CrossRef] [PubMed]

63. Hall-Stoodley, L.; Costerton, J.W.; Stoodley, P. Bacterial biofilms: From the natural environment to infectious diseases. Nat. Rev. Microbiol. 2004, 2, 95-108. [CrossRef] [PubMed]

64. Ferrer, M.D.; López-López, A.; Nicolescu, T.; Salavert, A.; Méndez, I.; Cuñé, J.; Llena, C.; Mira, A. A pilot study to assess oral colonization and $\mathrm{pH}$ buffering by the probiotic Streptococcus dentisani under different dosing regimes. Odontology 2020, 108, 180-187. [CrossRef] [PubMed]

C 2020 by the authors. Licensee MDPI, Basel, Switzerland. This article is an open access article distributed under the terms and conditions of the Creative Commons Attribution (CC BY) license (http://creativecommons.org/licenses/by/4.0/). 